\title{
IAMJ
}

INTERNATIONAL

AYURVEDIC

MEDICAL JOURNAL

Case Report

ISSN: 2320-5091

Impact Factor: 6.719

\section{AYURVEDIC MANAGEMENT OF ANKYLOSING SPONDYLITIS - A CASE REPORT}

\author{
Saurav Verma \\ Ex-Assistant Professor, Dept. of Panchakarma \\ Sri Ganganagar College of Ayurvedic Science and Hospital, Sriganganagar (Rajasthan), India
}

Corresponding Author: sv8891@gmail.com

https://doi.org/10.46607/iamj3809072021

(Published Online: July 2021)

Open Access

(C) International Ayurvedic Medical Journal, India 2021

Article Received: 11/06//2021 - Peer Reviewed: 15/06/2021 - Accepted for Publication: 18/06/2021

Check for updates

\begin{abstract}
Ankylosing spondylitis (AS) is a chronic, systemic, inflammatory disease that affects primarily sacroiliac joints and the spine. It is a gradually progressive condition over several years until structural damage manifests clinically as sacroiliitis, loss of spinal mobility, extra-articular symptoms, peripheral arthritis and reduced quality of life. The onset is typically between the ages of 20 to 30, with a male preponderance of about 3:1. Modern science has very limited options to treat Ankylosing spondylitis. So, the necessity of management through Ayurveda is very much essential. Various Panchakarma procedures and internal Ayurvedic medicines have been proved beneficial in the management of Ankylosing spondylitis. The present report deals with a case of 'Ankylosing spondylitis came to our hospital for Ayurvedic treatment. The patient was diagnosed as having 'Asthi-Majja Gata Vata' according to Ayurveda and treated with various Panchakarma procedures and internal medicines for 60 days. A criterion of assessment was based on the scoring of 'Bath Ankylosing Spondylitis Disease Activity Index (BASDAI)'. Total two assessments were carried out before and after 60 days of treatment. The patient has shown good improvement on BASDAI (80\% relief). Improvement was found in signs and symptoms like fatigue/tiredness, back/hip pain, tenderness and intensity as well as the duration of morning stiffness. Ayurvedic treatment seems to be promising in the management of Ankylosing spondylitis without causing any adverse effects.
\end{abstract}


Keywords: Ankylosing spondylitis; Asthi-Majja Gata Vata; Panchakarma; Ayurveda; Bath ankylosing spondylitis disease activity index (BASDAI)

\section{INTRODUCTION}

Ankylosing Spondylitis (AS) is characterized by chronic inflammatory arthritis predominantly affecting the sacroiliac joints and spine, which can progress to the bony fusion of the spine ${ }^{1}$. The onset is typically between the ages of 20 to 30 , with a male preponderance of about $3: 1^{2}$. The most common age of onset of symptoms is in the second and third decades of life. The prevalence of AS is generally believed to be between $0.1 \%$ and $1.4 \%$ globally while in India, around $0.25 \%$ population is estimated to be affected ${ }^{3}$. AS is a gradually progressive condition over several years until structural damage manifests clinically as sacroiliitis, loss of spinal mobility, extra-articular symptoms, peripheral arthritis and reduced quality of life. Patients with severe AS have a reduced quality of life, loss of productivity due to work disability and sick leave ${ }^{4}$. Non-steroidal anti-inflammatory drugs (NSAID), corticosteroids and various diseasemodifying ant rheumatic drugs (DMARDs) are used to treat/manage AS. However, these treatments are of limited benefit. Corticosteroids are associated with numerous side effects, especially when given systemically over long periods. No effective diseasemodifying treatment has been established for AS. AS commences as peripheral arthritis in $47 \%$, low back pain in $41 \%$, acute anterior uveitis in $10 \%$, and heel pain in $2 \%$ of the affected ${ }^{5}$. The cause of AS is multifactorial, as in many of the autoimmune diseases, based on endogenous factors, such as the very strong genetic influences of Human Leukocyte Antigen (HLA-B27) located at chromosome 6 and exogenous factors, such as bacterial infections especially gastrointestinal (with Salmonella, Shigella, Yersinia or Campylobacter) or urogenital (with Chlamydia trachomatis $)^{6}$. Unavailability of treatment not up to the mark in bio-medicine leads to permanent deformity in this disease. It is a need of the hour to explore satisfactory treatment modalities available in another medical system for the benefit of those affected. Regimented Ayurvedic intervention in the early stages of the illness reported being highly beneficial, in managing the symptoms as well as preventing further progression. Ayurveda interprets these changes as due to altered Vata Dosha resulting from the pathological factors that affect mainly the Asthi as well as the Majja Dhatu. Selected Panchakarma procedures are mentioned for the management in such conditions. Here a case is narrated that was successfully managed with the protocol for Asthimajjagata Vata.

Table 1: Modified New York criteria for diagnosis of $\mathrm{AS}^{6 *}$

Clinical criteria (Western perspective)

Low back pain of at least 3 months duration that is improved by exercise and not relieved by rest.

Limitation of the lumbar spine in sagittal and frontal planes

Chest expansion decreased relative to normal values for age and sex

Radiographic criterion

Unilateral grade 3 or 4 sacroiliitis or bilateral grade 2 sacroiliitis on plain radiograph

* A patient is classified as having definite Ankylosing spondylitis if the radiographic criterion is present and at least 1 clinical criterion is present.

Table 2: Ayurvedic Criteria

Subjective parameters

Bheda (pricking pain) in Kati Asthi

Bheda (pricking pain) in Kati Sandhi

Malabadhata

Satata (continous) Ruja

Balakshaya
Objective parameters

MRI

Degenerative Changes

Presence of Osteophytes 


\section{Case Study:}

A 48-year-old male came to Panchakarma OPD on 15/1/2019 in Sri Ganganagar College of Ayurvedic Sciences and Hospital, Sriganganagar with complaints of low backache, which is not radiating to any leg, stiffness (increased in morning time) associated with occasional numbness in the lower back region since 2 years but the pain got worse from 3 months. Pain worsens in the morning and night but decreases after $2 \mathrm{hr}$ after awakening. Gradually the pain developed in the lumbar region, and he felt difficulty in lying in the supine, standing as well as squatting positions. The patient was healthy for 2 years. When these symptoms developed, he consulted an allopathic physician, got temporary relief with the NSAID's as well as steroid therapy. Then he switched over to homoeopathic medicine and continued for almost 1 year, but the pain persisted. Then he commenced the Ayurvedic medicines at OP level but with no considerable relief. In January, he was admitted to this hospital for IP treatment, after that he got marked relief in the pain and his quality of life was also improved. For the time being, he again developed pain in the low back region for which got admitted again on $25 / 2 / 2019$. The case history was taken and elaborates all the Nidana Panchnakas given below.

\section{Nidana Panchnakas}

Dosa: - Vata (++), Kapha (+), Doosya: - Asthi, Majja and Sandhi, Agni: - Visamagni, Koshta: - Madhyama, Prakrthi: - Vata Pitta

\section{Investigation: -}

MRI- Sacralisation of L5 Vertebra and Degenerative Disc Disease L4-L5 Level

HLA-B27- Negative

\section{Diagnostic Focus and Assessment}

The patient had complained of incessant joint pain, fatigue and severely disturbed sleep resulting from pain. These symptoms point towards the condition of Asthimajjagata Vata as Asthibheda (stabbing pain in the bones), Parvabheda and Sandhi Shoola (pain in sacroiliac joint and cervical region). Bala Kshaya (decreased vitality and strength), Aswapana (sleeplessness) and Satataruk (continuous pain) are the manifestations of the same ${ }^{7}$. Adhyasthi (Fusion of the intervertebral disc) is the manifestation of Asthipradoshavikara (diseases of bones) ${ }^{8}$. Vinamata (kyphoscoliosis) is the manifestation of Majjavrita Vata $^{9}$. The patient was in Niramaavastha (stage of disease without $A m a$ ) condition with apparently normal appetite and approached as Nirama Vata Vyadhi (Vata disorder without Ama).

\section{THERAPEUTIC FOCUS AND ASSESSMENT}

Table 3: Panchakarma Procedure during I.P.D

\begin{tabular}{|c|c|c|c|}
\hline Date & Procedure & Medicine & Remarks \\
\hline $\begin{array}{l}15 / 1 / 19 \text { To } 21 / 1 / 19 \& 25 / 2 / 19 \text { To } \\
12 / 03 / 19\end{array}$ & $\begin{array}{l}\text { Valuka } \\
\text { Swedana }\end{array}$ & ------- & Stiffness relived \\
\hline $\begin{array}{l}22 / 1 / 19 \text { To } 29 / 1 / 19 \& \text { \& } 25 / 2 / 19 \text { To } \\
\text { 12/03/19 }\end{array}$ & Yoga Basti & $\begin{array}{l}\text { Niruh Basti with Dashmoola } \\
\text { and Anuvasana with Sahcharadi Taila }\end{array}$ & $\begin{array}{l}\text { Pain Reduced and } \\
\text { Comfortable }\end{array}$ \\
\hline Purvakarma before Basti & $\begin{array}{l}\text { Snehana \& } \\
\text { Swedana }\end{array}$ & $\begin{array}{l}\text { Snehana with Kottamchukadi Taila and } \\
\text { Bhaspa Swdana with Dashmoola } \\
\text { Kwath }\end{array}$ & $\begin{array}{l}\text { For attaining Dra- } \\
\text { veekarana of Dhathu- } \\
\text { gata Dosha }\end{array}$ \\
\hline
\end{tabular}

Table 4: Shamana Aushadhi during I.P.D:

\begin{tabular}{|l|l|l|}
\hline Medicine & Dose & Time \\
\hline Yograj Guggulu & $2-\operatorname{tab} B D$ & After food \\
\hline Avipatikar Choorna & $3 g m B D$ & Before food \\
\hline Panchkola Choorna & $3 g m$ & After food \\
\hline Gandharvahastadi Kwatha & $25 \mathrm{ml}$ & After food \\
\hline
\end{tabular}


Assessment: Assessment of the effect of the therapy was done based on changes observed at the clinical level. A numerical score was assigned for each of the signs and symptoms by using the Visual analogue scale (VAS).

Table 5: Bath Ankylosing Spondylitis Disease Activity Index (BASDAI)

\begin{tabular}{|l|l|l|l|l|l|}
\hline SYMPTOMS & BT & AT & AT & $2^{\text {nd }}$ Shift & $2^{\text {nd }}$ Shift \\
\hline Fatigue & $1^{\text {st }}$ day & $1^{\text {st }} w e e k$ & $2^{\text {nd }} w e e k$ & $1^{\text {st }}$ week & $2^{\text {nd }}$ week \\
\hline Back pain, Hip pain (VAS) & More & Less & Less & Less & Less \\
\hline Morning stiffness- intensity (VAS) & 100 & 90 & 50 & 60 & 25 \\
\hline Morning stiffness -duration (Approx.) & 100 & 95 & 40 & 55 & 35 \\
\hline
\end{tabular}

\section{DISCUSSION}

The condition was approached and managed with the principles of management of Asthimajjagata Vata. In Asthimajjagata Vatavyadhi, two main events are contributing to the pathogenesis of the disease. They are the Kshaya of the Asthidhatu and the Vata Prakopa. According to Ayurveda, Asthi Dhatu and Vata Dosha have Asraya-Asrayee Bandha ${ }^{10}$ in which the factor causing Kshaya of Vata Dosha gradually leads to Vrdhi of Asthi Dhatu and vice versa leading to a vicious cycle in the pathogenesis. ${ }^{11}$ Rukhsa Swedana helps to remove the Avarana of Kapha. So, the first Valuka Swedana was done for the first 7 days of treatment to remove the stiffness present due to Kapha Dosha. After this Yoga Basti planned for the next 8 days. In the next shift, Valuka Swedana and Kala Basti were given to the patient. The ultimate Upakrama mentioned for Vata disorder is Basti. Nirooha Basti Dravyas are having the properties of Snigdha Guna plays an important role in pacifying Vata $^{12}$ and Tikta Rasa drugs having Soshana and Khara Gunas like Asthidhatu, resulting in Asthidhatu Vrdhi as per the Samanya Vishesha Sidhanta ${ }^{13}$. Vasti and Ghrita processed with Tikta Rasa are therefore indicated for Asthimajja pathology in the classics. ${ }^{14}$ Foods and drugs having sweet and bitter properties are indicated in Majja-pradoshajavikaras.

\section{CONCLUSION}

Ankylosing Spondylitis is not mentioned as a separate entity in the Ayurvedic classical texts. But considering the symptoms and the cause, the disease can be approached with the concept of Vatavyadhi with special reference to Asthimajjagata Vata. After assessing the associative Doshas and Ama status if any, the protocol is to be designed along with the administration of internal medicines. This combined Ayurvedic treatment of the above mentioned oral Ayurvedic drugs and Panchakarma procedures had given promising results in the management of AS. This approach may be taken into consideration for further treatment and studies must be conducted in this regard, so that we can effectively use the Ayurvedic principles for helping the affected mankind in such conditions.

\section{REFERENCES}

1. Brian R. Walker, Nicki H. Colledge, Stuart H. Ralston, Ian D. Penman, Davidson's Principles and Practice of medicine, Edition-22. Page No. 1105.

2. Calin A, Fries JF. Striking prevalence of ankylosing spondylitis in "healthy" w27 positive males and females. A controlled study. New England Journal of medicine 1975; 293:835-839.

3. Linda E. Dean, Gareth T. Jones, Alan G. MacDonald, Christina Downham, Roger D. Sturrock, Gary J. Macfarlane; Global prevalence of ankylosing spondylitis; Rheumatology (Oxford) (2014) 53 (4): 650-657.

4. https://www.ncbi.nlm.nih.gov/pubmed/12381506

5. S Prakash, N K Mehra, S Bhargava, M C Vaidya, and A N Malaviya; ankylosing spondylitis in North India: a clinical and immunogenetic study. Annual of the Rheumatic Disease. 1984 Jun; 43(3): 381-385

6. I.E. van der Horst-Bruinsma, MD, PhD Book: Ankylosing spondylitis, diagnosis and treatment. version 19-1-05 final; Chapter 3 Clinical aspects of Ankylosing Spondylitis 
7. Pandey G., editor. Pt. KashinathSastri Vidhyotini Hindi Commentator of Charaka Samhita of Agnivesa. Vol. 2. Chaukumba Sanskrit Sansthan; Varanasi: 2006. p. 782. (Chikitsa Sthan Vatavyadhi Chikitsa Adhayay). Ch. 28, Ver. 33.

8. Pandey G., editor. Pt. KashinathSastri Vidhyotini Hindi Commentator of Charaka Samhita of Agnivesa. Vol. 1. Chaukumba Sanskrit Sansthan; Varanasi: 2006. p. 572. (Sutra Sthan Vivdhasitapitiya Adhyay). Ch. 28, Ver. 16.)

9. Pandey G., editor. Pt. Kashinath Sastri Vidhyotini Hindi Commentator of Charaka Samhita of Agnivesa. Vol. 2. Chaukumba Sanskrit Sansthan; Varanasi: 2006. p. 789. (Chikitsa Sthan Vatavyadhi Chikitsa Adhayay). Ch. 28, Ver. 66.)

10. . Ashtangahridya, of vagbhatta, by Kaviraj atridev Gupta, Chaukhabha prakashana, Varanasi, reprint 2007, Sootrastana 11/26.

11. Ashtangahridya, of vagbhatta, by Kavirajatridev Gupta, Chaukhabha prakashana, Varanasi, reprint - 2007, Sootrastana 11/27.

12. Ashtangahridya, of vagbhatta, by Kaviraj atridev Gupta, Chaukhabha prakashana, Varanasi, reprint -2007 , Sootrastana 13/3

13. Ashtangahridya, of vagbhatta, by Kaviraj atridev Gupta, Chaukhabha prakashana, Varanasi, reprint - 2007, Sootrastana $1 / 14$

14. Ashtangahridya, of vagbhatta, by Kaviraj atridev Gupta, Chaukhabha

\section{Source of Support: Nil \\ Conflict of Interest: None Declared}

How to cite this URL: Saurav Verma: Ayurvedic Management Of Ankylosing Spondylitis - A Case Report. International Ayurvedic Medical Journal \{online\} 2021 \{cited July 2021\} Available from: http://www.iamj.in/posts/images/upload/1555_1559.pdf 